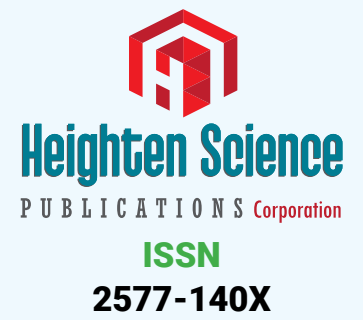

*Address for Correspondence: Tongabay Cumurcu, Inonu University School of Medicine, Malatya, Turkey, Tel: 90-422-342 06 60/4003; Fax: 90-422-3410728; Email:

tongabay@superonline.com

Submitted: 20 April 2017

Approved: 26 June 2017

Published: 28 June 2017

Copyright: @ 2017 Cumurcu T. This is an open access article distributed under the Creative Commons Attribution License, which permits unrestricted use, distribution, and reproduction in any medium, provided the original work is properly cited.
Review Article

\section{Mitomycin-C Use and Complications in Ophthalmology}

\author{
Tongabay Cumurcu* \\ Inonu University School of Medicine, Department of Ophthalmology, Malatya, Turkey
}

\section{INTRODUCTION}

Mitomycin-C, first found its way into ophthalmic use in 1969, in Japan, where recurrent pterygia were successfully treated with the drug which is an antineoplastic / antibiotic agent isolated from the soil bacterium Streptomyces caespitosus [1]. It is an anti-metabolite with anti-proliferative effect on cells showing the highest rate of mitosis by inhibiting DNA synthesis and interferes with RNA transcription and protein synthesis [2].

\section{CLINICAL USES}

Mitomycin-C should be reconstituted in sterile water at neutral $\mathrm{pH}$, the drug is inactivated in an acidic solution. The drug should be stored under refrigeration to preserve its potency under these conditions, Mitomycin- $\mathrm{C}$ is potent for a period of two weeks [3].

\section{DRUG RECONSTITUTION AND PHARMACOKINETICS}

The drug is available in a vial $(2 \mathrm{mg} / \mathrm{ml}$ and $10 \mathrm{mg} / \mathrm{ml})$. It is further reconstituted with normal saline either $5 \mathrm{ml}$ for $2 \mathrm{mg} / \mathrm{ml}$ vial to make $0.4 \mathrm{mg} / \mathrm{ml}$ solution or $10 \mathrm{ml}$ for $2 \mathrm{mg} / \mathrm{ml}$ vial to make $0.2 \mathrm{mg} / \mathrm{ml}$ solution [3]. MMC is delivered in solubilized form. It has high bio-availability in the target tissue because of its hydrophobic character, which favors its penetration into the epithelially denuded cornea and conjunctiva, while deterring its movement into or through intact epithelium [1].

\section{Uses of mitomycin C in ophthalmolgy}

- Ocular surface tumors

- Pterygium surgery

-Glaucoma surgery

- Dacryocystorhinostomy

- Squint surgeries

- Refractive surgeries

- Allergic conjunctivitis and vernal keratoconjunctivitis

\section{Complications}

The dosage, the route of delivery/application, the time of exposure and the area of tissue that encounters MMC are important when considering complication rate. Higher MMC concentrations and prolonged exposure times may be associated with a higher risk of complications. 


\section{Ocular surface tumours and Pterygium}

Ocular surface tumors include a variety of neoplasms originating from the squamous epithelium, melanocytes, and lymphocytic resident cells of the conjunctival stroma.(4) $0.2-0.4 \mathrm{mg} / \mathrm{ml}$ applied intra-operatively over bare sclera for 1-5 minutes.Among the most impressive results with ocular surface tumors were double masked, prospective trial using doses of $0.4 \mathrm{mg} / \mathrm{ml}(0.04 \%)$ and $1 \mathrm{mg} / \mathrm{ml}$ four times daily for two weeks [2]. Other reports also describe good results with no serious complications using $0.2 \mathrm{mg} /$ $\mathrm{ml}$ of Mitomycin-C [5].

\section{Complications}

Corneal melting and perforation, corneal edema, seconder glaucoma, scleral calcification. In addition pain, prolonged hyperemia, late hemorrhage, chemosis, lid edema, excessive tearing, ptosis, wound dehiscence, corneal blood staining, photopobia,pigment accumulation, superficial punctate keratitis and delayed wound healing are other rare complications of Mitomycin-C. Periocular allergic contact dermatitis and limbal stem cell deficiency are also important complications of MMC in the treatment of ocular surface tumors [2].

\section{Glaucoma surgery}

In filtration surgery of glaucoma, subconjunctival or scleral scarring at bleb cause to high failure rate of trabeculectomy. Mitomycin C use to inhibits the fibroblasts proliferation and subsequent scarring of filtration bleb in filtration surgery. Intraoperative Mitomycin C applied at concentration of $0.2 \mathrm{mg} / \mathrm{ml}$ controlled postoperative intraocular pressure as effectively as a $0.4 \mathrm{mg} / \mathrm{ml}$ concentration in high risk cases of congenital glaucoma, but with lower incidence of complications and thin walled blebs [6].

There is no significant difference success or complication between subconjunctival and intra-scleral application of MMC augmented trabeculectomies in glaucomatous eyes at high risk of surgical failure [7].

\section{Administration}

Merocel sponge applyed in the desired concentration is kept for 1-5 minutes generally subconjunctival and sometimes subscleral $(0.2 \mathrm{mg} / \mathrm{ml}$ or $0.4 \mathrm{mg} / \mathrm{ml})$. After that thoroughly washed with balanced salt solution.

\section{Complications}

Cause of late bleb leaks, bleb infections, endophthalmitis, thin walled cystic blebs, corneal epithelial toxicity, corneal or scleral melting, hypotony and hypotonic maculopathy.

\section{Refractive surgeries}

After corneal refractive surface surgery. haze formation with loss of corneal transparency, surface irregularities and myopic regression, are the major complications. The use of Mitomycin-C is intended to inhibit wound healing mechanisms leading to sub-epithelial fibrosis. Although some studies suggest that lower concentrations $(0.01 \%, 0.002 \%)$ could also be effective in preventing haze when treating low to moderate myopia, Mitomycin-C is usually applied at a concentration of $0.2 \mathrm{mg} /$ $\mathrm{ml}(0.02 \%)$ for 12 to 120 seconds over the ablated stroma in laser-assisted in situ keratomileusis (LASIK). Single application of diluted MMC $0.02 \%$ solution following scraping of the corneal surface was effective and safe in treating haze and regression after photorefractive keratotomy (PRK) for myopia. This dose of MMC has not been associated with any clinically relevant epithelial corneal toxicity [8]. 


\section{Dacryocystorhinostomy (DCR)}

The major cause of DCR failure is fibrosis occurring under the flaps near the osteotomy area. Mitomycin C is used over the anastomosed flaps and osteotomy area to inhibits fibrous proliferation and scar formation. A piece of cotton soaked with $0.2 \mathrm{mg} / \mathrm{ml} \mathrm{MMC}$ is applied to the osteotomy area for 5-30 minutes intra-operatively is safe and effective in maintaining a larger osteotomy size and also improves success rates over the traditional DCR procedure (4.5\% vs $11.4 \%$ ) [9]. A dose ranging from 0.02 to $0.04 \%$ applied for a durationof 5 to 30 minutes is effective and no significant complications resulted from its use.

\section{Squint surgeries}

The intraoperative application of mitomycin $C$ is a safe and effective adjunct to surgery in the treatment of restrictive strabismus. Topical Mitomycin-C may enhance the success rate of strabismus surgery with delayed adjustment and reduce postoperative adhesions [10]. Mitomycin C when applied intraoperatively helps in reducing postoperative adhesions following strabismus surgery. Dose: $0.2 \mathrm{mg} / \mathrm{ml}$ for 5 minutes between the conjunctiva and the sclera after adhesion release.

\section{Allergic conjunctivitis and Vernal Keratoconjunctivitis (VKC)}

In a study topical Mitomycin-C $(0.2 \mathrm{mg} / \mathrm{ml})$ was applied four times a day for 3 months and was found to be safe and effective alternative to topical azelastine, in treating allergic conjunctivitis [11]. Topical Mitomycin-C (0.01\%) three times daily for a period of two weeks is an effective and safe drug to control acute exacerbations in patients of severe VKC refractory to conventional treatment [12].

\section{General ocular Complications of topical Mitomycin-C}

Photophobia, ocular pain, lacrimation, foreign body sensation (secondary to superficial punctate keratitis) and eye lid edema are cauntable as minor comlications of topical Mitomycin-C [3]. Scleral and corneal ulceration and perforation, hypotony, necrotizing scleritis, endophthalmitis, iridocyclitis, cataract, glaucoma and symblepharon are rare and major complications of topical Mitomycin-C [3].

\section{Contraindications of Mitomycin-C for topical use}

One-eyed patients, pregnant women, very old patients, severe dry eye, those with predisposing condition to corneal ulceration or poor healing such as immunocompromised patients or patients with Sjogren's syndrome, atopic keratoconjunctivitis, acne rosacea or herpetic keratitis [3].

\section{CONCLUSION}

The dose and duration of application of Mitomycin C is still controversial. The use of topical Mitomycin C in ophthalmology is increasing in every subspeciality but risk benefit ratio should be considered, keeping in mind its complications. Further studies are needed to establish the safety and efficacy of this drug.

\section{REFERENCES}

1. Kunitomoro N, Mori S. Studies on pterygium: Part 4, a treatment of pterygium by Mitomycin-C installation. Acta Soc Ophthalmol Jpn 1969; 67: 601-607.

2. Singh P, Singh A. Mytomicin-C Use in Ophthalmology. IOSR Journal of Pharmacy. 2013; 3: 12-14. Ref.: https://goo.gl/bsz4qv

3. Mudhol R, Zingade ND, Mudhol RS. Mitomycin C in Ophthalmology. Journal of the Scientific Society. 2012; 39: 4-6. Ref.: https://goo.gl/MQfsio

4. Salmon SE, Sartorelli AC. Cancer chemotherapy. In: Katzung BG, editors. Basic and clinical pharmacology. 6th ed. Norwalk, CT: Appleton and Lange. 1995; Chap. 56. 
5. Hayasaka S, Noda S, Yamamoto Y, Setogawa T. Postoperative instillation of low-dose mitomycin $C$ in the treatment of primary pterygium. Am J Ophthalmol. 1988; 106: 715. Ref.: https://goo.gl/i62iHp

6. Agarwal HC, Sood NN, Sihota R, Sanga L, Honavar SG. Honavar SG Mitomycin-C in congenital glaucoma Ophthalmic Surg Lasers. 1997; 28: 979-85. Ref.: https://goo.gl/4m3QKD

7. Agarwal HC, Saigal D, Sihota R. Assessing the role of subconjunctival versus intrascleral application of Mitomycin-C in highrisk trabeculectomies. Indian J Ophthalmol. 2001; 49: 91-95. Ref.: https://goo.gl/qejWSu

8. Vigo L, Scandola E, Carones F. Scraping and Mitomycin C to treat haze and regression after photorefractive keratectomy for myopia. J Refract Surg. 2003; 19: 449-454. Ref.: https://goo.gl/SaQMbk

9. Kao SC, Liao CL, Tseng JH, Chen MS, Hou PK. Dacryocystorhinostomy with intraoperative Mitomycin C. Ophthalmology. 1997; 104: 86-91. Ref.: https://goo.gl/mMhqzi

10. Oh SO, Chang BL, Lee J. Effects of Mitomycin C on delayed adjustment in experimental strabismus surgery. Korean J Ophthalmol. 1995 ; 9: 51-58. Ref.: https://goo.gl/UQakEe

11. Sodhi PK, Pandey RM, Ratan SK. Efficacy and safety of topical azelastine compared with topical Mitomycin C in patients with allergic conjunctivitis. Cornea. 2003; 22: 210-213. Ref.: https://goo.gl/kqjZBa

12. Jain AK, Sukhija J. Low dose Mitomycin-C in severe vernal keratoconjunctivitis: a randomized prospective double blind study. Indian J Ophthalmol. 2006; 54: 111-116. Ref.: https://goo.gl/VBnPk9 